\title{
Phytochemical Characterization, Pharmacological Properties And Toxicity of Amazonian Fruit Cubiu (Solanum Sessiliflorum Dunal)
}

Jéssica Franco Dalenogare ( $\nabla$ jessicafrancodalenogare@yahoo.com.br)

Universidade Federal de Santa Maria

Sabrina Somacal

Universidade Federal de Santa Maria

Vanessa Schopf Machado

Universidade Federal de Santa Maria

Greice Franciele Feyh dos Santos Montagner

Universidade Federal de Santa Maria

Camila Marina Verdi

Universidade Federal de Santa Maria

Marta Maria Medeiros Frescura Duarte

Universidade Federal de Santa Maria

Tatiana Emanuelli

Universidade Federal de Santa Maria

Roberto Christ Vianna Santos

Universidade Federal de Santa Maria

Michele Rorato Sagrillo

Universidade Franciscana

Liliane de Freitas Bauermann

Universidade Federal de Santa Maria

\section{Research Article}

Keywords: antimicrobial, antioxidant, anti-inflammatory, skin wound healing, cocona

Posted Date: August 18th, 2021

DOI: https://doi.org/10.21203/rs.3.rs-766797/v1

License: (c) (i) This work is licensed under a Creative Commons Attribution 4.0 International License.

Read Full License 


\section{Abstract}

The cubiu (Solanum sessiliflorum) is a tropical fruit native to the Amazon region and widely used in medicine and cosmetics, despite the lack of research regarding the actual safety and effectiveness of its use for these purposes. This study aimed to evaluated the phytochemical characterization, pharmacological properties (skin wound healing, antimicrobial and anti-inflammatory properties), and toxicity of cubiu extract. The cubiu antimicrobial capacity was determined against strains of Aeromonas caviae, Pseudomonas aeruginosa, and Sphingomonas paucimobilis. Additionally, cubiu toxicity (hemolysis, coagulation, cell viability, and genotoxicity tests), antioxidant activity (reactive oxygen species total levels), scratch assay (in vitro skin wound healing), and anti-inflammatory activity against phytohemagglutinin and in the scratch assay (Interleukin 1, interleukin 6, interleukin 10, tumor necrosis factor-alpha, and interferon-gamma levels), were evaluated. Human fibroblast cells were used to evaluate skin wound healing, and human peripheral blood mononuclear cells were used for the other assessments. Our findings showed that the cubiu extract is rich in phenolic compounds, the major compound being 5caffeoylquinic acid. In addition, was effective against the three bacterial strains tested and inhibited and destroyed the biofilm formed by Pseudomonas aeruginosa. The cubiu extract also was no toxicity, maintained the hemocompatibility parameters in the biological range, improved cell viability, decreased reactive oxygen species total levels and pro-inflammatory cytokine levels, increased anti-inflammatory cytokine levels, and accelerated the wound healing process. In conclusion, this is the first research to prove that cubiu is an important compound for use in the skin diseases, promoting skin wound healing, antimicrobial and anti-inflammatory activities.

\section{Introduction}

Solanum sessiliflorum Dunal (cubiu) is a tropical plant of the Solanaceae family and native to the Amazon region. Its fruit, cubiu, also known as "apple/peach tomato", has become an important raw material for the modern agro-industry, considering it comes from a highly productive and easily cultivated fruit that is widely consumed and nutritious with health-promoting components. In food its used in numerous ways such as juices, sweets, jellies and consumed in natura ${ }^{1}$.

Popularly cubiu is used as a medicine and cosmetic, albeit there is a lack of scientific data confirming the safety and effectiveness of its use for these purposes. Hence, hypoglycemic, hypolipidemic, and antioxidant properties are attributed to the use of cubiu, which is also commonly used to treat diabetes, hypertension and several other pathologies ${ }^{2}$. These properties attributed to the cubiu are likely due to its phenolic-rich composition ${ }^{3}$, also, the cubiu has high iron, niacin, citric acid, and pectin content, favoring health as a whole ${ }^{1}$.

Furthermore, cubiu is popularly used as a treatment for skin diseases, mainly for infections and skin wound healing ${ }^{4-6}$, albeit without scientific data confirming this activety so far. Regarding the skin wound healing, it is known that for a treatment to be effective, its must have antimicrobial and anti-inflammatory 
activities as its action mechanisms, which improve and accelerate the skin wound healing, keeping the skin intact and without infection ${ }^{7,8}$.

Given the above, this study aimed to determine the phytochemical characterization and pharmacological potential of cubiu, by investigating its skin wound healing, antimicrobial and anti-inflammatory properties, and investigating its toxicity and safety.

\section{Methodology}

\subsection{Cubiu extract preparation}

The present research is part of a project previously authorized by the Brazil Environmental Ministry to assess the components of genetic patrimony in national territory ( $\left.{ }^{\circ} 010547 / 2013-4\right)$, according to Brazilian legislation ( $\mathrm{n}^{\circ}$ 2186-16). Cubiu samples, approximately $20 \mathrm{~kg}$, was commercially acquired in the Municipal Market Adolfo Lisboa - Manaus city, Amazonas, Brazil. A botanic specialist Eduardo Vellez Marin (CRBio 09112-03) confirmed the fruits to be Solanum sessiliflorum Dunal. The material was registered in the Management of Genetic Patrimony Council, Brazil (CGEN, process number A6723EB).

To obtain the cubiu extract, the fresh fruits $(147 \pm 38 \mathrm{~g})$ were washed, peeled and the pulp with small seeds was triturated using a mixer (particles $\leq 3 \mathrm{~mm}$ ) for approximately $5 \mathrm{~min}$ and placed into sealed amber glass containers with 70\% absolute ethanol (Neon, commercial-03467; São Paulo, SP, Brazil), where they remained for seven days with solvent exchanged three times. After extraction, the product obtained was filtered, evaporated, and then lyophilized ${ }^{9}$. The use of fresh fruit followed institutional, national and international guidelines and legislation.

\subsection{Cubiu extract phytochemical characterization}

The phytochemical characterization of the cubiu extract was carried out by detecting the presence of phenolic and carotenoid compounds by high-performance liquid chromatography with a diode array detector (HPLC-DAD) according to Quatrin et al. ${ }^{10}$ and Rosso and Mercadante ${ }^{11}$, respectively. The chromatograms for phenolic quantification purposes were obtained at $280 \mathrm{~nm}$ for hydroxybenzoates and tannins, $320 \mathrm{~nm}$ for hydroxycinnamates, $360 \mathrm{~nm}$ for flavonols, and $450 \mathrm{~nm}$ for carotenoids. All compounds were identified by comparing with the retention time of authentic standards and the spectral data obtained from UV-visible absorption spectra.

Stock solutions of phenolic compounds and carotenoid standard references were prepared in the initial mobile phase and diluted in eight equidistant points within the concentration range of LOQ-60 $\mathrm{mg} \mathrm{L}^{-1}$. The calibration curves of the phenolic compounds are as follows: gallic acid: $y=79089 x+81326(r=$ 0.998); chlorogenic acid (5-caffeoylquinic acid): $y=90494 x+497491(r=0.997)$; quercetin: $y=64434 x-$ $373423(r=0.895)$, and (all-E)- $\beta$-carotene $y=19095 x-6503.8(r=0.999)$. The limits of detection (LOD) and quantification (LOQ) for gallic acid, chlorogenic acid, quercetin, and (all-E)- $\beta$-carotene were 0.012 and $0.037 \mathrm{ppm}, 0.099$ and $0.330 \mathrm{ppm}, 0.146$ and 0.444 , and 0.089 and $0.25 \mathrm{ppm}$, respectively. 
Hydroxybenzoate derivatives were quantified as equivalent to gallic acid, hydroxycinnamate derivatives were quantified as equivalent to chlorogenic acid, and the results were expressed as mg per $100 \mathrm{~g}$ of dry sample weight (mean \pm standard deviation).

\subsection{Antimicrobial activity}

\subsubsection{Microbial strains and inoculum preparation}

The antibacterial activity was evaluated against standard strains of Aeromonas caviae (ATCC 15468), Pseudomonas aeruginosa (PA01), and Sphingomonas paucimobilis (CCT 7809). These strains belong to the Laboratory of Oral Microbiology (LAPEMICRO) bacterial collection of the Federal University of Santa Maria (UFSM), which granted us permission to obtain the strains. The inoculum was prepared after bacterial growth $\left(24 \mathrm{~h}\right.$ and $\left.35^{\circ} \mathrm{C} \pm 2\right)$ on Mueller-Hinton agar. Colonies were suspended in sterile saline solution $(0.85 \%)$ and adjusted to 0.5 on the McFarland scale ( 1 to $2 \times 10^{8}$ colony-forming units). For the broth microdilution assay, the standardized inoculum was diluted in a 1:10 ratio.

\subsubsection{Minimum inhibitory concentration and minimum bactericidal concentration determination}

To performed the antimicrobial and antibiofilm activity tests, the lyophilized cubiu extract was diluted in Mueller Hinton broth. Cubiu extract activity was evaluated on a dose-response curve at the concentrations of $0.01,0.03,0.1,0.3,1,3,10$, and $30 \mathrm{mg} / \mathrm{mL}$. Trials were performed in triplicate on three different days to ensure data reliability, and assays followed the standard protocols for each microbial group according to the Clinical and Laboratory Standards Institute (CLSI) M7-A9 (2015) ${ }^{12}$.

The minimum inhibitory concentration (MIC) was determined by the broth microdilution method using sterile 96 -well plates. The plates were prepared and incubating at $37^{\circ} \mathrm{C}$ and, after the incubation period, the presence/absence of growth was observed. After the MIC reading, $10 \mu \mathrm{L}$ were removed from the wells with the absence of growth, seeded, and reincubated at $37^{\circ} \mathrm{C}$. The absence of growth characterized the minimum bactericidal concentration (MBC); positive and negative growth controls were performed in all tests.

\subsubsection{Biofilm formation inhibition and biofilm destruction}

According to Antunes et al. ${ }^{13}$, biofilm formation inhibition and biofilm destruction were analyzed by the crystal violet assay, using 96-well microtiter plates. The crystal violet retained in the adhered cells was dissolved with $200 \mu \mathrm{L}$ of $95 \%$ absolute alcohol during $10 \mathrm{~min}$ and bacterial growth was quantified by measuring the optical density (OD) at $570 \mathrm{~nm}$ with a spectrophotometer (Spectra-max M2e Multimode Microplate Reader, Molecular Devices, USA). The results are demonstrated as absorbance values.

\subsection{Experimental cell assays}

In vitro experimental assays were conducted using peripheral blood mononuclear cells (PBMC) for toxicity assays (Cell viability evaluation using MTT assay, Fluorimetric DNA quantification assay using 
PicoGreen reagent, Reactive oxygen species quantification - 2'-7'dichlorofluorescin diacetate assay, Nitric oxide determination) and erythrocytes for the Hemolytic activity and Coagulation tests. Also, PBMC were used in the evaluation of anti-inflammatory activity with phytohemagglutinin. Human fibroblast (HFF-1) cells were also used as an experimental model to investigate the potential skin wound healing effects of the cubiu extract.

The cubiu extract was tested at concentrations of 10 and $30 \mathrm{mg} / \mathrm{mL}$ since these were the concentrations chosen according to the concentration-effect curve of the previous assays. The extract was diluted in cell culture medium, and all treatments and assays were performed in triplicate. Hydrogen peroxide $\left(\mathrm{H}_{2} \mathrm{O}_{2}\right)$ at $100 \mu \mathrm{M}$ was used as a positive control (PC) group in all tests, while just the cell group in the culture medium was used as a negative control (NC) group.

\subsubsection{Cell culture}

The PBMCs and erythrocytes derived from discarded total peripheral blood samples from healthy adults, with no identification data, were obtained from the Laboratory of Clinical Analysis of the Franciscan University (LEAC-UFN). This experimental protocol was approved by the Ethics Committee on Human Beings of the Franciscan University (CAAE 31211214.4.0000.5306), the ethics committee released this study from the presentation of informed consent, since these are discard samples and do not have identification data. All experiments were performed in accordance with the institutional, national and international guidelines and legislation, also the research was conducted in accordance with the 1964 Helsinki Declaration and its later amendments, and in agreement with national international and institutional rules.

Blood samples were initially processed to isolate the PBMCs using a density gradient difference protocol based on Ficcol Histopaque-1077® reagent (Sigma-Aldrich St Louis, MO, USA). After placing the blood in the reagent $(1: 1 \mathrm{v} / \mathrm{v})$, the samples were centrifuged for $30 \mathrm{~min}$ at room temperature. The PBMCs were plated in 96-well plates with RPMI-1640 cell medium (Sigma-Aldrich St Louis, MO, USA) containing 10\% fetal bovine serum and supplemented with $1 \%$ antibiotics. The cells were cultured at a concentration of $2 \times 10^{5}$ cells $/ \mathrm{mL}$ per well ${ }^{14}$.

The Human fibroblasts HFF-1 cell line (ATCC $\AA$, CRL-2468TM), were obtained commercially from the Rio de Janeiro Cell Bank. The cells were thawed and maintained in polystyrene bottles in culture medium according to the American Type Culture Collection (ATCC), containing 10\% fetal bovine serum (Invitrogen) inactivated at $56^{\circ} \mathrm{C}$ for $1 \mathrm{~h}, 100 \mathrm{U} / \mathrm{mL}$ penicillin (Invitrogen), and $100 \mathrm{U} / \mathrm{mL}$ streptomycin (Invitrogen) at $37^{\circ} \mathrm{C}$ in a humid atmosphere containing $5 \% \mathrm{CO}_{2}$. Weekly replicates were performed in laminar flow in order for each bottle to receive $5 \mathrm{~mL}$ of medium with a fixed amount of cells at the time of the replicate $\left(2 \times 10^{5}\right.$ cells $\left./ \mathrm{mL}\right)$. After obtaining a satisfactory confluence for the experimental trials, the cells were seeded in 96 -well plates $\left(2 \times 10^{5}\right.$ cells $/ \mathrm{mL}$ per well), and the dilutions were made in a culture medium specific for the cell line applied.

\subsubsection{Hemocompatibility tests}




\subsubsection{Hemolytic activity}

Hemocompatibility tests were performed according to Souza Filho et al. ${ }^{15}$. Blood was added with a phosphate-buffered saline (PBS) $1 \mathrm{X}$ solution (1:1 v/v) and centrifuged for $15 \mathrm{~min}$ at $1000 \mathrm{rpm}$, and the supernatant was discarded (procedure performed three times). Afterward, $50 \mu \mathrm{L}$ of washed red blood cells and $10 \mu \mathrm{L}$ of treatment were added to microtubes containing $1 \mathrm{~mL}$ of PBS $1 \mathrm{X}$ at different $\mathrm{pH}(\mathrm{pH} 7.2$ to simulate sepsis due to metabolic acidosis, $\mathrm{pH} 7.4$ to simulate the body's normal pH, and pH 7.5 to simulate alkalinity). The control groups were as follows: NC (red cells $+0.9 \%$ sodium chloride), PC (red cells + distilled water), and surfactants (red cells + surfactant mixture, Tween $60+$ Span 60) at the same concentrations of the treatments. The tubes were incubated at room temperature and under rotation for 1 h. Subsequently, they were centrifuged for $15 \mathrm{~min}$ at $1000 \mathrm{rpm}$, followed by transferring $200 \mu \mathrm{L}$ of the supernatant to a $96-w e l l$ plate read on an ELISA reader at $540 \mathrm{~nm}$. The results were expressed as a percentage of the negative control.

\subsubsection{Coagulation test}

The coagulation test was carried out according to Souza Filho et al. ${ }^{15}$. Total blood levels were collected in a citrate tube and centrifuged for $10 \mathrm{~min}$ at $2500 \mathrm{rpm}$. Then, $225 \mu \mathrm{L}$ of plasma was placed in 96-well plates with $25 \mu \mathrm{L}$ of treatments and incubated at $37^{\circ} \mathrm{C}$ for $30 \mathrm{~min}$. Two independent experiments were performed in duplicate with different donors. Readings were carried out on the coagulometer Quick Timer II (Drake) that had been previously calibrated according to the manufacturer's recommendations for tests of hemostasis prothrombin time (PT; Labtest - Lot no.: 4008) and activated partial thromboplastin time (aPTT; Labtest - Lot no.: 4006). For the normal aPTT value, the range between 25 and $35 \mathrm{~s}$ was used as a reference, while the range between 11 and $15 \mathrm{~s}$ was used for the baseline values of PT 16,17.

\subsubsection{Toxicity assays}

\subsubsection{Cell viability evaluation using MTT assay}

The MTT (3-(4,5-dimethylthiazol-2-yl) -2,5-diphenyltetrazolium bromide) assay was performed as described by Fukui et al. ${ }^{18}$. Upon completion of the incubation time of the cells with the treatments, 20 $\mu \mathrm{L}$ of MTT solution ( $0.01 \mathrm{M}$ and $\mathrm{pH} 7.4$ ) at $5 \mathrm{mg} / \mathrm{mL}$ diluted in PBS (1X phosphate buffer saline) was added. Afterward, the plates were protected from light and incubated in an incubator at $37^{\circ} \mathrm{C}$ for $2 \mathrm{~h}$. Subsequently, the supernatant was removed from the wells and the cells resuspended in $150 \mu \mathrm{L}$ of dimethyl sulfoxide (DMSO). Absorbance was read on an ELISA reader at $560 \mathrm{~nm}$. The results were expressed as a percentage of the negative control.

\subsubsection{Fluorimetric DNA quantification assay using PicoGreen reagent}

The free DNA in the medium was quantified using the PicoGreen reagent (Invitrogen Life Technologies, Carlsbad, USA) and performed according to Sagrillo et al. ${ }^{19}$. The PicoGreen reagent was added to the 
sample in 96 -well ELISA plates after being incubated in an oven at $37^{\circ} \mathrm{C}$ for $5 \mathrm{~min}$, and fluorescence reading was performed on a spectrofluorometer ( $480 \mathrm{~nm}$ excitation and $520 \mathrm{~nm}$ emission). The results were expressed as a percentage of the negative control.

\subsubsection{Reactive oxygen species quantification - 2'-7'dichlorofluorescin diacetate assay}

Reactive oxygen species (ROS) were quantified as described by Esposti et al. ${ }^{20}$, and the sample $(50 \mu \mathrm{L})$, Tris buffer $(60 \mu \mathrm{L})$, and 2',7'-dichlorofluorescein diacetate reagent (10 $\mu \mathrm{L} ; \mathrm{DCFH}-\mathrm{DA})$ were added to the 96 well ELISA plates. The plates were protected from light and incubated in an oven at $37^{\circ} \mathrm{C}$ for $1 \mathrm{~h}$.

Fluorescence reading was carried out on an ELISA reader (488 nm excitation and $525 \mathrm{~nm}$ emission). The results were expressed as a percentage of the negative control.

\subsubsection{Nitric oxide determination}

The nitric oxide (NO) levels were measured according to Choi et al. ${ }^{21}$ and Noh et al. ${ }^{22} .50 \mu \mathrm{L}$ of the sample was pipetted in a 96-well plate, followed by adding $50 \mu \mathrm{L}$ of Griess reagent, and maintained for $15 \mathrm{~min}$ at room temperature and protected from light. After, the reading was performed in the spectrophotometer at $540 \mathrm{mn}$, and the results were expressed as a percentage of the negative control.

\subsubsection{Evaluation of anti-inflammatory activity with phytohemagglutinin}

The protocol was performed according to Maczynski et al. ${ }^{23}$. The PBMCs $\left(2 \times 10^{5}\right.$ cells/well) were plated in 96-well plates with $50 \mu \mathrm{L}$ of phytohemagglutinin (PHA) and incubated at $37^{\circ} \mathrm{C}$ with $5 \% \mathrm{CO}_{2}$ for $48 \mathrm{~h}$. Then, the cells were washed with PBS ( $1 \mathrm{X} ; \mathrm{Gibco})$ and the treatments were carried out and incubated once again for another $24 \mathrm{~h}$. After this period, the plates were centrifuged and the supernatant was removed for MTT (as described in 2.4.3.1) and NO (as described in 2.4.3.4) assays. As a negative control, cells that were untreated or stimulated by PHA were used, and untreated and PHA-stimulated cells were used as a positive control.

\subsubsection{Inflammatory cytokines}

Inflammatory cytokine levels were analyzed in the anti-inflammatory activity with PHA (item 2.4.4) and in vitro skin wound healing scratch assay (item 2.4.6). Interleukin 1 (IL-1), interleukin 6 (IL-6), interleukin 10 (IL-10), tumor necrosis factor-alpha (TNF-a), and interferon-gamma (INF- $\gamma$ ) levels were evaluated using a human ELISA kit (eBioscience, San Diego, USA) according to the manufacturer's instructions.

Homocysteine levels were analyzed using an Immulite analyzer (Diagnostic Products Corporation, Los Angeles, USA). The results are expressed in $\mathrm{pg} / \mathrm{mL}$.

\subsubsection{In vitro skin wound healing - scratch assay}

The HFF-1 cells were used for the in vitro skin wound healing assay. A line was drawn in the middle of each well of the plate using a permanent marker to better standardize the scratch and measurements 
before plating the cells. This marking established a visual field in the well, which was analyzed after making the scratch in the monolayer. The cells were plated in a 96-well plate and, after confluence/adhesion, the culture medium was removed. With the help of a needle, a continuous scratch was then made on the medial surface of each well, and this procedure led to a rupture of the contact between the cells and their removal from a certain region of the plate, thus forming a mechanical lesion in the cell monolayer. The wells were washed with PBS (Gibco) to remove the debrided cells according to the method of Seeliger et al. ${ }^{24}$, and the treatments were performed. Thereafter, the proliferation of adjacent cells towards the free space in the plate was followed at $48 \mathrm{~h}$ with the recording of photographic images.

To analyze the images of the skin wound healing process, was used a script in the Python programming language, according to rossato et al. ${ }^{25}$, that quantifies the number of cells present in the samples, and thus establishes the percentage of skin wound healing. The results are demonstrated as a percentage of the cells.

\subsection{Statistical analysis}

The GraphPad Prism (version 5.0; GraphPad Software, La Jolla, USA) software was used for statistical analyses and to create the figures. Data were expressed as mean \pm standard deviation. The homogeneity of variances was verified with Levene's test and treatments were compared using one-way analysis of variance (ANOVA) followed by Tukey's post hoc test, and $p<0.05$ was considered significant.

\section{Results}

\subsection{Cubiu extract characterization}

Cubiu extract used in this study had its composition evaluated by HPLC-DAD and the chromatographic profile is shown in Fig. 1. Due to the polarity characteristics of the solvent (ethanol $70 \%$ ) used during the extraction process, only phenolic compounds were found in the lyophilized extract. However, traces of lutein were observed, albeit in quantities below the LOQ (data shown in supplementary data S1 online). The total phenolic compound content in the cubiu extract was $456.31 \pm 19.78 \mathrm{mg} / 100 \mathrm{~g}$ of lyophilized extract. Phenolic compounds found can be classified into two groups of phenolic acids: hydroxybenzoic $(11.61 \pm 3.50 \mathrm{mg} / 100 \mathrm{~g})$ and hydroxycinnamic $(444.70 \pm 16.28 \mathrm{mg} / 100 \mathrm{~g})$. The major compound identified was 5 -caffeoylquinic acid, which had a concentration of $392.92 \pm 13.25 \mathrm{mg} / 100 \mathrm{~g}$ of extract, corresponding to $84 \%$ of the compounds quantified.

\subsection{Microbiology}

\subsubsection{Minimum inhibitory concentration and minimum bactericidal concentration determination}


According to our findings, the cubiu treatment acted as a bacteriostatic and bactericide against Aeromonas caviae, P. aeruginosa (PA01), and Sphingomonas paucimobilis strains. Assay susceptibility $(\mathrm{mg} / \mathrm{mL})$ of cubiu extract against standard strains (MIC and MBC values) are shown in Table 1.

Table 1

- Assay in vitro susceptibility of cubiu extract against standard strains.

\begin{tabular}{|lll|}
\hline Microorganism & \multicolumn{2}{l|}{ Cubiu (Solanum sessiliflorum) } \\
\cline { 2 - 3 } & MIC & MBC \\
\hline Aeromonas caviae (ATCC 15468) & $10 \mathrm{mg} / \mathrm{mL}$ & $30 \mathrm{mg} / \mathrm{mL}$ \\
\hline Pseudomonas aeruginosa PA01 & $30 \mathrm{mg} / \mathrm{mL}$ & $30 \mathrm{mg} / \mathrm{mL}$ \\
\hline Sphingomonas paucimobilis (ATCC 7809) & $10 \mathrm{mg} / \mathrm{mL}$ & $10 \mathrm{mg} / \mathrm{mL}$ \\
\hline ATCC: American Type Culture Collection. & & \\
\hline
\end{tabular}

\subsubsection{Biofilm inhibition and biofilm destruction}

For $P$. aeruginosa (PA01), which are biofilm-producing bacteria, the analysis of biofilm inhibition and destruction was performed, and it was possible to observe that all tested concentrations of the cubiu extract inhibited biofilm formation and destroyed the biofilm previously formed (Fig. 2). The treatment with cubiu extract, in the crystal violet assay, showed a decrease $36,53 \%$ and $35,06 \%$ the inhibited of biofilm formation when treated with $15 \mathrm{mg} / \mathrm{mL}$ and $30 \mathrm{mg} / \mathrm{mL}$, respectively (Fig. 2a) when compared with positive control. Moreover, the destroyed of biofilm previously formad showed a decrease $49,64 \%$ and $42,17 \%$ when treated with $15 \mathrm{mg} / \mathrm{mL}$ and $30 \mathrm{mg} / \mathrm{mL}$ of cubiu extract, respectively (Fig. $2 \mathrm{~b}$ ) when compared as positive control.

\subsection{Experimental cell assays \\ 3.3.1 Hemocompatibility tests}

\subsubsection{Hemolytic activity}

Hemolytic activity was not altered by any treatment at pH 7.2 (acidosis), pH 7.4 (physiological), and pH 7.5 (alkalosis), as illustrated in Fig. 3a, 3b, and 3c, respectively.

\subsubsection{Coagulation test}

There were no results outside the biological range in the PT (Fig. 3d) and aPTT (Fig. 3e) tests.

\subsubsection{Toxicity assays}

\subsubsection{Cell viability evaluation by MTT assay}


Cubiu extract treatments at doses of 10 and $30 \mathrm{mg} / \mathrm{mL}$ improved cell viability compared to the PC group (Fig. 4a).

\subsubsection{Fluorimetric DNA quantification assay using PicoGreen reagent}

The results for detecting double-stranded DNA damage in cell culture are shown in Fig. 4b, in which no DNA damage was observed at any of the tested concentrations.

\subsubsection{Reactive oxygen species quantification - 2'-7'dichlorofluorescin diacetate assay}

Treatments with 10 and $30 \mathrm{mg} / \mathrm{mL}$ of cubiu extract showed antioxidant activity, with lower total ROS levels than the PC group (Fig. 4c).

\subsubsection{Nitric oxide determination}

There were no changes in NO levels from the treatment (Fig. 4d).

\subsubsection{Evaluation of anti-inflammatory activity with phytohemagglutinin}

The anti-inflammatory activity with PHA of the cubiu extract was evaluated, and the results showed that anti-inflammatory activity at 10 and $30 \mathrm{mg} / \mathrm{mL}$ led to a sharp drop in IL-1, IL-6, TNF-a, and INF-y levels compared to the PC, as well as an increase in IL-10 levels compared to the PC (Fig. 5a, 5b, 5c, 5d, 5e respectively). Furthermore, the MTT assay revealed that, through the treatments with 10 and $30 \mathrm{mg} / \mathrm{mL}$, it was possible to resume the basal levels of cell viability, in addition to no alterations in NO levels (Fig. $5 f$ and $5 \mathrm{~g}$ respectively).

\subsubsection{In vitro wound skin wound healing - scratch assay}

The cubiu extract (10 and $30 \mathrm{mg} / \mathrm{mL}$ ) proved to have skin wound healing properties compared to the NC and PC groups (Fig. 6a). Moreover, the samples in both concentrations acted as anti-inflammatory agents during the skin wound healing process due to the significant decrease in pro-inflammatory cytokine levels (IL-1, IL-6, TNF-a and INF- $\gamma$ ) compared to the PC, as well as the increased anti-inflammatory cytokines (IL10) compared to the PC (Fig. 6b, 6c, 6d, 6e, 6f respectively).

\section{Discussion}

This study aimed to investigate the pharmacological potential of cubiu extract, a tropical fruit of Solanum sessiliflorum and native to the Amazon region. Cubiu is rich in fiber, minerals, iron, niacin, citric acid, and pectin ${ }^{26}$, and the presence of phenolic compounds stands out in its composition, including chlorogenic acid and, more specifically, 5-caffeoylquinic acid as the major compound ${ }^{3}$. In agreement with the above, we also found phenolic compounds in the cubiu extract, with 5-caffeoylquinic acid being the major 
compound. Hence, it is seen that Solanaceae plants have caffeoylquinic acids in their composition to which are attributed several of their biological activities that benefit human health 27 .

We first investigated the antimicrobial activity of the cubiu extract. From a curve with concentrations of $0.01,0.03,0.1,0.3,1,3,10$, and $30 \mathrm{mg} / \mathrm{mL}$ of cubiu extract, we showed that 10 and $30 \mathrm{mg} / \mathrm{mL}$ have bacteriostatic and bactericidal activity against Aeromonas caviae, Sphingomonas paucimobilis, $P$. aeruginosa (PA01), which are bacteria that affect various tissues, e.g., the skin, and cause mild and severe infections in hospitals ${ }^{28-30}$.

Furthermore, knowing that PA01 is a multidrug-resistant biofilm-producing bacterium ${ }^{31}$, we also tested the cubiu extract effectiveness in inhibiting biofilm formation and destroying this biofilm when previously formed by PA01. We evidenced that the cubiu extract was effectively in the inhibition biofilm formation by PA01 and destroy the biofilm previously formed by this bacterium at all concentrations tested $15 \mathrm{mg} / \mathrm{mL}$ and $30 \mathrm{mg} / \mathrm{mL}$ ). Biofilm is mainly associated with prolonged infections and an important mechanism used by microorganisms to survive antibiotic treatments. Additionally, the biofilm formed by PA01 is closely related to infections in chronic skin wounds ${ }^{31,32}$.

Various conventional antimicrobial agents have become less effective against microorganisms as they have become increasingly resistant, making the search for new alternatives with antimicrobial activity indispensable. Thus, research with medicinal plants is a crucial alternative to treat different infectious diseases, as many of these plants have bioactive components with antimicrobial properties ${ }^{33,34}$. Therefore, plant extracts and their constituents are being used to combat numerous resistance mechanisms of microorganisms ${ }^{35,36}$.

Given this scenario, we can highlight the potential use of the cubiu extract as a bacteriostatic and bactericidal agent to prevent and treat bacterial biofilms, and the antimicrobial potential exerted by this fruit can be justified by the phenolic substances in its chemical matrix. Among the bioactive substances, phenolic substances are highly relevant concerning antimicrobial properties ${ }^{37}$. In a similar study, Rodrigues et al. ${ }^{38}$ corroborate our findings by demonstrating that pitanga (Eugenia uniflora L.) extract was effective against bacterial biofilm, attributing this result to the presence of phenolic substances in the fruit extract.

Evidence suggests that the possible mechanism of antimicrobial compounds is related to the cascade of reactions involving the bacterial cell ${ }^{39,40}$. These reactions may involve the antioxidant capacity of phenolic compounds, which may be important in the antimicrobial mode of action since these natural compounds can reduce the production of essential metabolites for microorganism survival under stress conditions. Hence, it is plausible that the cubiu extract attached and incorporate itself to the biofilm structure, impairing signaling pathways and inducing the disruption of cell membrane ${ }^{41,42}$.

Knowing that concentrations of 10 and $30 \mathrm{mg} / \mathrm{mL}$ of cubiu extract have promising biological activities, it is vital to verify if these concentrations are safe to use. Therefore, we followed up on the toxicity study of 
the cubiu extract using PBMC, and our findings revealed that the cubiu extract did not present toxicity due to maintaining hemolysis and blood coagulation patterns within the biological range. In addition, the cubiu extract did not cause alterations or damage to double-stranded DNA, alter NO levels, and improved cell viability. Moreover, Hernandes et al. ${ }^{43}$ reported that cubiu does not present cytotoxic or genotoxic effects, further echoing that its safe to consume.

Furthermore, the cubiu extract at the tested concentrations decrease ROS total levels, thus demonstrating antioxidant action. Kaunda et al. ${ }^{44}$ also reported that different species of the genus Solanum exhibit antioxidant properties, and Morais et al. ${ }^{27}$ described Solanaceae species as having antioxidant potential mainly due to their chemical matrices, including phenolic substances. These, in turn, are widely known for their antioxidant and chelating properties ${ }^{45}$.

High ROS levels, at the expense of the body's antioxidant capacity, are known to cause oxidative stress, promoting cellular damage in plasma membranes, lipids, and proteins and even culminating in cell death. Moreover, oxidative stress is closely linked with the inflammatory response since lipid peroxidation causes inflammatory enzymes such as cyclooxygenase and lipoxygenase to be stimulated and induces leukocytes to release pro-inflammatory cytokines ${ }^{46}$. Cytokines are importants inflammatory mediators and can be pro-inflammatory, thus being responsible for manifesting and propagating inflammatory (e.g., IL-1, IL-6, TNF-a and INF-g) or anti-inflammatory (e.g., IL-10) responses and acting as an inhibitor of the inflammatory process 47,48 .

The phenolic substances present in Solanaceae plants also provide anti-inflammatory properties ${ }^{27}$, as demonstrated herein with the cubiu extract. Therefore, by using PBMCs, we aimed to verify the antiinflammatory properties of the cubiu extract against PHA, a natural agent inducer of inflammatory responses ${ }^{23}$. From this experiment, it was possible to evidence that the cubiu extract ( 10 and $30 \mathrm{mg} / \mathrm{mL}$ ) has anti-inflammatory activity, restoring cell viability, maintaining NO levels unchanged, decreasing proinflammatory cytokine levels (IL-1, IL-6, TNF-a and INF-g), and increasing anti-inflammatory cytokine levels (IL-10).

Phenolic substances have anti-inflammatory activity given their ability to inhibit enzymes such as prostaglandin synthetase, lipoxygenase, and cyclooxygenase, which are involved in the inflammatory process. Moreover, it is also known that chlorogenic acid, which is present in the composition of cubiu, interferes with the response of leukocytes to chemokines, also preventing the interaction with adhesion molecules involved in cell migration during the inflammatory process ${ }^{49}$.

In addition, the anti-inflammatory activity of cubiu was also evidenced in the scratch assay using HFF-1 cells, as both cubiu extract concentrations decreased pro-inflammatory cytokine levels (IL-1, IL-6, TNF-a, and INF-g) and increased anti-inflammatory cytokine levels (IL-10). Furthermore, the scratch assay demonstrated the skin wound healing potential of the cubiu extract. It is known that phenolic substances present in natural extracts have skin wound healing properties ${ }^{50,51}$. The cubiu is popularly used for skin wound healing 4,5 , albeit without scientific data so far. The present study is the pioneer to prove this 
activity, as shown herein, both concentrations (10 and $30 \mathrm{mg} / \mathrm{mL}$ ) of the cubiu extract improved skin wound healing.

It is widely known that treatments that improve skin wound healing should promote antimicrobial, antiinflammatory, and antioxidant activities since infections, prolonged inflammatory processes, and oxidative stress delay the skin wound healing process ${ }^{7,8}$. As for the cubiu extract, we proved that all of these indispensable properties that enhance skin wound healing are found in it, therefore justifying the significant skin wound healing potential of this tropical fruit at the concentrations tested. This is the first research to prove that cubiu extract is an important compound for use in the skin diseases, promoting skin wound healing, antimicrobial and anti-inflammatory activities.

\section{Conclusions}

Considering the main focus of this research, we seek to demonstrated cubiu extract phytochemical composition, increasing knowledge about the plant due to its importance in folk medicine. Additionally, we evaluated cubiu extract toxicity, its pharmacological properties in skin wound healing, antimicrobial activity against strains that affect the skin, anti-inflammatory and antioxidante activities. All data demonstrate that cubiu extract has no toxicity and its an important compound for use in the skin diseases, may be used for the treatment skin wound healing and skin infections, promoting also antiinflammatory and antioxidant activities.

\section{Declarations}

Author contribution: All authors participated in the conception, design, study and interpretation of cited references, analysis of the results wrote and review of the manuscript. LFB guided and supervised all stages of the research. JFD designed the research, participated in all experimental stages, wrote the manuscript. GFFSM responsible for obtaining and preparing the fruits and hydroalcoholic extract. TE and SS performed phytochemical analysis of the extract. RCV, VSM and CMV participated in the analysis and results of microbiology. MRS Performed the analyzes and results regarding peripheral blood mononuclear cells and human fibroblastos. MMFD performed inflammatory cytokine analysis. All au-thors read and approved the manuscript. The authors declare that all datawere generated in-house and that no paper mill was used.

Conflict of interest: The authors declare no competing interests.

Data Availability Statement: All data generated or analysed during this study are included in this published article (and its Supplementary Information files).

Funding: this work was supported by CAPES - Coordenação de Aperfeiçoamento de Pessoal de Nível Superior, under Grant 88882.428091/2019-01. 
Ethics approval: The PBMCs and erythrocytes derived from discarded total peripheral blood samples from healthy adults, with no identification data, were obtained from the Laboratory of Clinical Analysis of the Franciscan University (LEAC-UFN). This experimental protocol was approved by the Ethics Committee on Human Beings of the Franciscan University (CAAE 31211214.4.0000.5306), the ethics committee released this study from the presentation of informed consent, since these are discard samples and do not have identification data. All experiments were performed in accordance with the institutional, national and international guidelines and legislation, also the research was conducted in accordance with the 1964 Helsinki Declaration and its later amendments, and in agreement with national international and institutional rules.

\section{References}

1. Colodel, C., Bagatin, R., Tavares, T. \& Petkowicz, C. Cell wall polysaccharides from pulp and peel of cubiu: A pectin-richfruit. Carbohydr. Polym, 174, 226-234 https://doi.org/10.1016/j.carbpol.2017.06.052 (2017).

2. Silva Filho, D., Yuyama, L., Aguiar, J., Oliveira, M. \& Martin, L. Caracterização e avaliação do potencial agronômico e nutricional de etnovariedades de cubiu (Solanum sessiliflorum Dunal) da Amazônia. Acta Amaz, 35, 399-406 https://doi.org/10.1590/S0044-59672005000400003 (2005).

3. Rodrigues, E., Mariutti, L. R. B. \& Mercadante, A. Z. Carotenoids and phenolic compounds from Solanum sessiliflorum, an unexploited amazonian fruit, and their scavenging capacities against reactive oxygen and nitrogen species. J. Agric. Food Chem, 61, 3022-3029 https://doi.org/10.1021/jf3054214 (2013).

4. Sila Filho, D. F., de da, Andrade, J. S., Clement, C. R., Machado, F. M. \& Noda, H. Correlações fenotípicas, genéticas e ambientais entre descritores Morfológicos e Químicos em frutos de Cubiu (Solanum sessiliflorum Dunal) da Amazônia1. Acta Amaz, 29, 503-511 https://doi.org/10.1590/1809-43921999294511 (1999).

5. Schuelter, A. R. et al. In vitro regeneration of cocona (Solanum sessiliflorum, Solanaceae) cultivars for commercial production. Genet. Mol. Res, 8, 963-975 https://doi.org/10.4238/vol8-3gmr613 (2009).

6. Jiménez, P. Cocona- Solanum sessiliflorum. Exot. Fruits 153-158(2018) doi:10.1016/b978-0-12803138-4.00020-4. https://doi.org/10.1016/b978-0-12-803138-4.00020-4.

7. Gonzalez, A., Andrade, Z., Fortuna, T. \& Medrado, A. Wound healing - A literature review. An. Bras. Dermatol, 91, 614-620 https://doi.org/10.1590/abd1806-4841.20164741 (2016).

8. Pazyar, N., Yaghoobi, R., Rafiee, E., Mehrabian, A. \& Feily, A. Skin wound healing and phytomedicine: A review. Skin Pharmacol. Physiol, 27, 303-310 https://doi.org/10.1159/000357477 (2014).

9. Dos Santos Montagner, G. F. F. et al. In Vitro Biological Properties of Solanum sessiliflorum (Dunal), an Amazonian Fruit. J. Med. Food, 23, 978-987 https://doi.org/10.1089/jmf.2019.0193 (2020).

10. Quatrin, A. et al. Characterization and quantification of tannins, flavonols, anthocyanins and matrixbound polyphenols from jaboticaba fruit peel: A comparison between Myrciaria trunciflora and M. 
jaboticaba. J. Food Compos. Anal, 78, 59-74 https://doi.org/10.1016/j.jfca.2019.01.018 (2019).

11. De Rosso, V. V. \& Mercadante, A. Z. Identification and quantification of carotenoids, by HPLC-PDAMS/MS, from Amazonian fruits. J. Agric. Food Chem, 55, 5062-5072 https://doi.org/10.1021/jf0705421 (2007).

12. National Committee for Clinical Laboratory Standards, N. M02-A12. Performance Standards for Antimicrobial Disk Susceptibility Tests; Approved Standard-Twelfth Edition. Clin. Lab. Stand. Inst, 35, 73 (2015).

13. Antunes, A. L. S. et al. Application of a feasible method for determination of biofilm antimicrobial susceptibility in staphylococci. Apmis, 118, 873-877 https://doi.org/10.1111/j.16000463.2010.02681.x (2010).

14. Pires, C. W. et al. Induction of cytotoxicity, oxidative stress and genotoxicity by root filling pastes used in primary teeth. Int. Endod. J, 49, 737-745 https://doi.org/10.1111/iej.12502 (2016).

15. Sousa Filho, W. P. et al. Effects of nanocapsules containing all-trans-retinoic acid under hemolytic and coagulation activity. Arch. Biosci. Heal, 1, 125-138 https://doi.org/10.18593/abh.16726 (2019).

16. Salvador-Morales, C., Zhang, L., Langer, R. \& Farokhzad, O. C. Immunocompatibility properties of lipid-polymer hybrid nanoparticles with heterogeneous surface functional groups., 30, 2231-2240 https://doi.org/10.1016/j.biomaterials.2009.01.005 (2009).

17. Adamson, P. C. et al. Variability in the oral bioavailability of all-trans-retinoic acid. J. Natl. Cancer Inst, 85, 993-996 https://doi.org/10.1093/jnci/85.12.993 (1993).

18. Fukui, M., Yamabe, N. \& Zhu, B. T. Resveratrol attenuates the anticancer efficacy of paclitaxel in human breast cancer cells in vitro and in vivo. Eur. J. Cancer, 46, 1882-1891 https://doi.org/10.1016/j.ejca.2010.02.004 (2010).

19. Sagrillo, M. R. et al. Tucumã fruit extracts (Astrocaryum aculeatum Meyer) decrease cytotoxic effects of hydrogen peroxide on human lymphocytes. Food Chem, 173, 741-748 https://doi.org/10.1016/j.foodchem.2014.10.067 (2015).

20. Esposti, M. Measuring mitochondrial reactive oxygen species., 26, 335-340 https://doi.org/10.1016/s1046-2023(02)00039-7 (2002).

21. Choi, W. S., Shin, P. G., Lee, J. H., Kim, G. \& Do The regulatory effect of veratric acid on NO production in LPS-stimulated RAW264.7 macrophage cells. Cell. Immunol, 280, 164-170 https://doi.org/10.1016/j.cellimm.2012.12.007 (2012).

22. Noh, H. J. et al. Anti-inflammatory activity of a new cyclic peptide, citrusin XI, isolated from the fruits of Citrus unshiu. J. Ethnopharmacol, 163, 106-112 https://doi.org/10.1016/j.jep.2015.01.024 (2015).

23. Mączyński, M. et al. Anti-inflammatory properties of an isoxazole derivative - MZO-2. Pharmacol. Reports, 68, 894-902 https://doi.org/10.1016/j.pharep.2016.04.017 (2016).

24. Seeliger, C., Falldorf, K., Sachtleben, J. \& Van Griensven, M. Low-frequency pulsed electromagnetic fields significantly improve time of closure and proliferation of human tendon fibroblasts. Eur. $J$. Med. Res, 19, 1-7 https://doi.org/10.1186/2047-783X-19-37 (2014). 
25. Rossato, A. et al. Evaluation of anti-inflammatory and healing activity of a nano-structured lipid carrier containing tucuman butter oil and butter. Discip. Sci. - Ciências Nat. e Tecnológicas, 21, 99$108 \mathrm{https} / / /$ doi.org/10.37779/nt.v21i3.3551 (2020).

26. Colodel, C., Bagatin, R. M., das, G., Tavares, T. M. \& de Petkowicz, C. L. O. Cell wall polysaccharides from pulp and peel of cubiu: A pectin-rich fruit. Carbohydr. Polym, 174, 226-234 https://doi.org/10.1016/j.carbpol.2017.06.052 (2017).

27. Morais, M. G. et al. Chemical composition, antioxidant, anti-inflammatory and antinociceptive activities of the ethanol extract of ripe fruits of Solanum lycocarpum St. Hil. (Solanaceae). J. Ethnopharmacol, 262, 113125 https://doi.org/10.1016/j.jep.2020.113125 (2020).

28. Ryan, M. P. \& Adley, C. C. Sphingomonas paucimobilis: A persistent Gram-negative nosocomial infectious organism. J. Hosp. Infect, 75, 153-157 https://doi.org/10.1016/j.jhin.2010.03.007 (2010).

29. Wu, D. C., Chan, W. W., Metelitsa, A. I., Fiorillo, L. \& Lin, A. N. Pseudomonas skin infection: Clinical features, epidemiology, and management. Am. J. Clin. Dermatol, 12, 157-169 https://doi.org/10.2165/11539770-000000000-00000 (2011).

30. Krishna, S. \& Miller, L. S. Host-pathogen interactions between the skin and Staphylococcus aureus. Curr. Opin. Microbiol, 15, 28-35 https://doi.org/10.1016/j.mib.2011.11.003 (2012).

31. Maunders, E. \& Welch, M. Matrix exopolysaccharides: The sticky side of biofilm formation. FEMS Microbiol. Lett, 364, https://doi.org/10.1093/femsle/fnx120 (2017).

32. Donlan, R. M., Costerton, J. W. \& Biofilms Survival mechanisms of clinically relevant microorganisms. Clin. Microbiol. Rev, 15, 167-193 https://doi.org/10.1128/CMR.15.2.167-193.2002 (2002).

33. Bua, A. et al. "In vitro" activity of Melaleuca cajuputi against mycobacterial species. Nat. Prod. Res, 34, 1494-1497 https://doi.org/10.1080/14786419.2018.1509335 (2020).

34. Maheshwari, M., Abul Qais, F., Althubiani, A. S., Abulreesh, H. H. \& Ahmad, I. Bioactive extracts of Carum copticum and thymol inhibit biofilm development by multidrug-resistant extended spectrum $\beta$ lactamase producing enteric bacteria., 35, 1026-1039 https://doi.org/10.1080/08927014.2019.1688305 (2019).

35. Algburi, A., Comito, N., Kashtanov, D., Dicks, L. M. T. \& Chikindas, M. L. Control of biofilm formation: Antibiotics and beyond. Appl. Environ. Microbiol, 83, e02508-16 https://doi.org/10.1128/AEM.02508-16 (2017).

36. Santos, C. A. et al. Bioactive Properties of Syzygium cumini (L.) Skeels Pulp and Seed Phenolic Extracts. Front. Microbiol, 11, https://doi.org/10.3389/fmicb.2020.00990 (2020).

37. Thakur, S., Ray, S., Jhunjhunwala, S. \& Nandi, D. Insights into coumarin-mediated inhibition of biofilm formation in Salmonella Typhimurium., 36, 479-491 https://doi.org/10.1080/08927014.2020.1773447 (2020).

38. Rodrigues, A. C. et al. Phenolic extract of Eugenia uniflora L. and furanone reduce biofilm formation by Serratia liquefaciens and increase its susceptibility to antimicrobials., $36,1031-1048$ https://doi.org/10.1080/08927014.2020.1844881 (2020). 
39. Da Rosa, J., Weber, G. G., Cardoso, R., Górski, F. \& Da-Silva, P. R. Variability and population genetic structure in Achyrocline flaccida (Weinm.) DC., a species with high value in folk medicine in South America. PLoS One, 12, 1-19 https://doi.org/10.1371/journal.pone.0183533 (2017).

40. Martínez-Busi, M. et al. Purification, structural elucidation, antioxidant capacity and neuroprotective potential of the main polyphenolic compounds contained in Achyrocline satureioides. Bioorganic Med. Chem, 27, 2579-2591 https://doi.org/10.1016/j.bmc.2019.03.047 (2019). Lam) D.C. (Compositae

41. Desbois, A. P. \& Smith, V. J. Antibacterial free fatty acids: Activities, mechanisms of action and biotechnological potential. Appl. Microbiol. Biotechnol, 85, 1629-1642 https://doi.org/10.1007/s00253-009-2355-3 (2010).

42. Dambolena, J. S., Zygadlo, J. A. \& Rubinstein, H. R. Antifumonisin activity of natural phenolic compounds. A structure-property-activity relationship study. Int. J. Food Microbiol, 145, 140-146 https://doi.org/10.1016/j.ijfoodmicro.2010.12.001 (2011).

43. Hernandes, L. et al. In vivo assessment of the cytotoxic, genotoxic and antigenotoxic potential of maná-cubiu (Solanum sessiliflorum Dunal) fruit. Food Res. Int, 62, 121-127 https://doi.org/10.1016/j.foodres.2014.02.036 (2014).

44. Kaunda, J. S. \& Zhang, Y. J. The Genus Solanum: An Ethnopharmacological, Phytochemical and Biological Properties Review. Natural Products and Bioprospecting vol, 9, https://doi.org/10.1007/s13659-019-0201-6 (Springer Singapore, 2019).

45. Yashin, A., Yashin, Y., Xia, X. \& Nemzer, B. Antioxidant Activity of Spices and Their Impact on Human Health: A Review. Antioxidants, 6, 70 https://doi.org/10.3390/antiox6030070 (2017).

46. Biswas, S., Das, R. \& Ray Banerjee, E. Role of free radicals in human inflammatory diseases. AIMS Biophys, 4, 596-614 https://doi.org/10.3934/biophy.2017.4.596 (2017).

47. Stunova, A. \& Vistejnova, L. Dermal fibroblasts - A heterogeneous population with regulatory function in wound healing. Cytokine Growth Factor Rev, 39, 137-150 https://doi.org/10.1016/j.cytogfr.2018.01.003 (2018).

48. Ramani, T. et al. Cytokines: The Good, the Bad, and the Deadly. Int. J. Toxicol, 34, 355-365 https://doi.org/10.1177/1091581815584918 (2015).

49. Chang, W. C., Chen, C. H., Lee, M. F., Chang, T. \& Yu, Y. M. Chlorogenic acid attenuates adhesion molecules upregulation in IL-1ß-treated endothelial cells. Eur. J. Nutr, 49, 267-275 https://doi.org/10.1007/s00394-009-0083-1 (2010).

50. Song, Y. et al. In vivo wound healing and in vitro antioxidant activities of Bletilla striata phenolic extracts. Biomed. Pharmacother, 93, 451-461 https://doi.org/10.1016/j.biopha.2017.06.079 (2017).

51. Jangde, R., Srivastava, S., Singh, M. R. \& Singh, D. In vitro and In vivo characterization of quercetin loaded multiphase hydrogel for wound healing application. Int. J. Biol. Macromol, 115, 1211-1217 https://doi.org/10.1016/j.jijbiomac.2018.05.010 (2018).

\section{Figures}


(a)

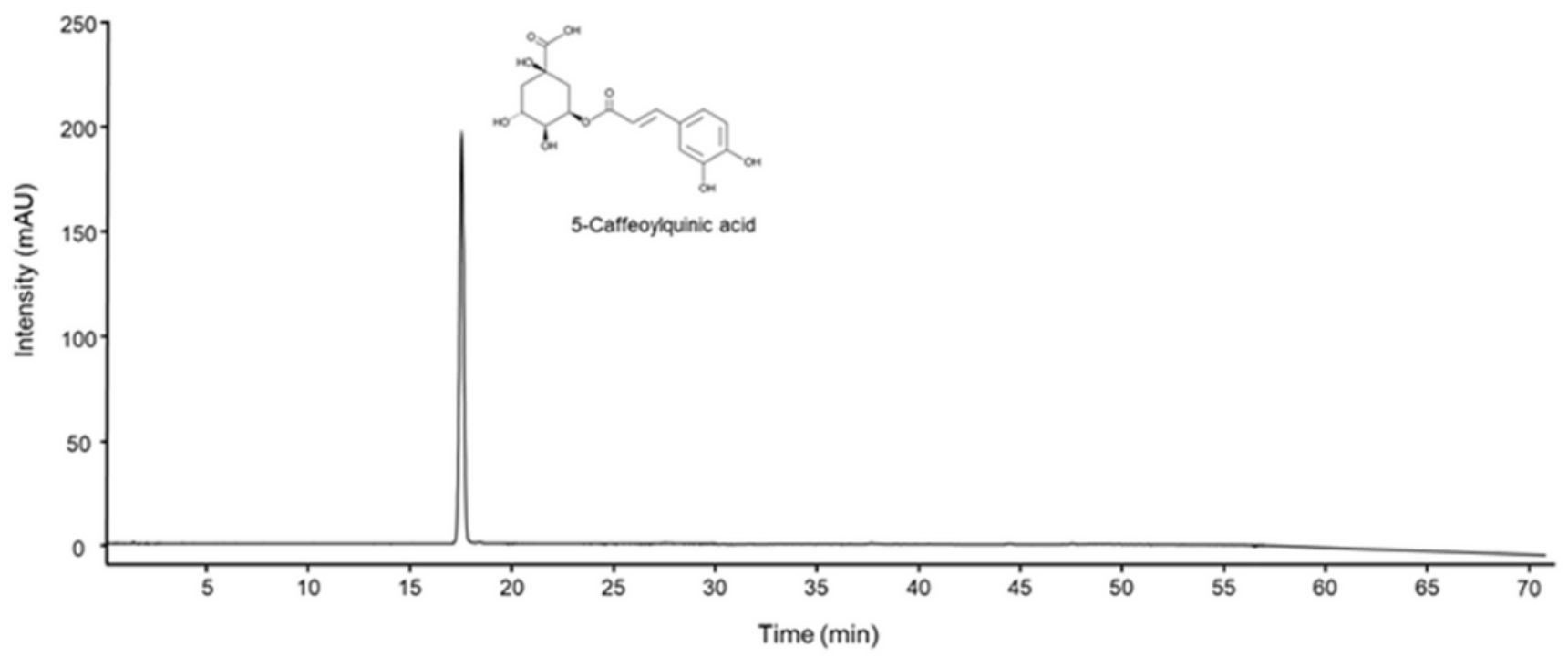

(b)

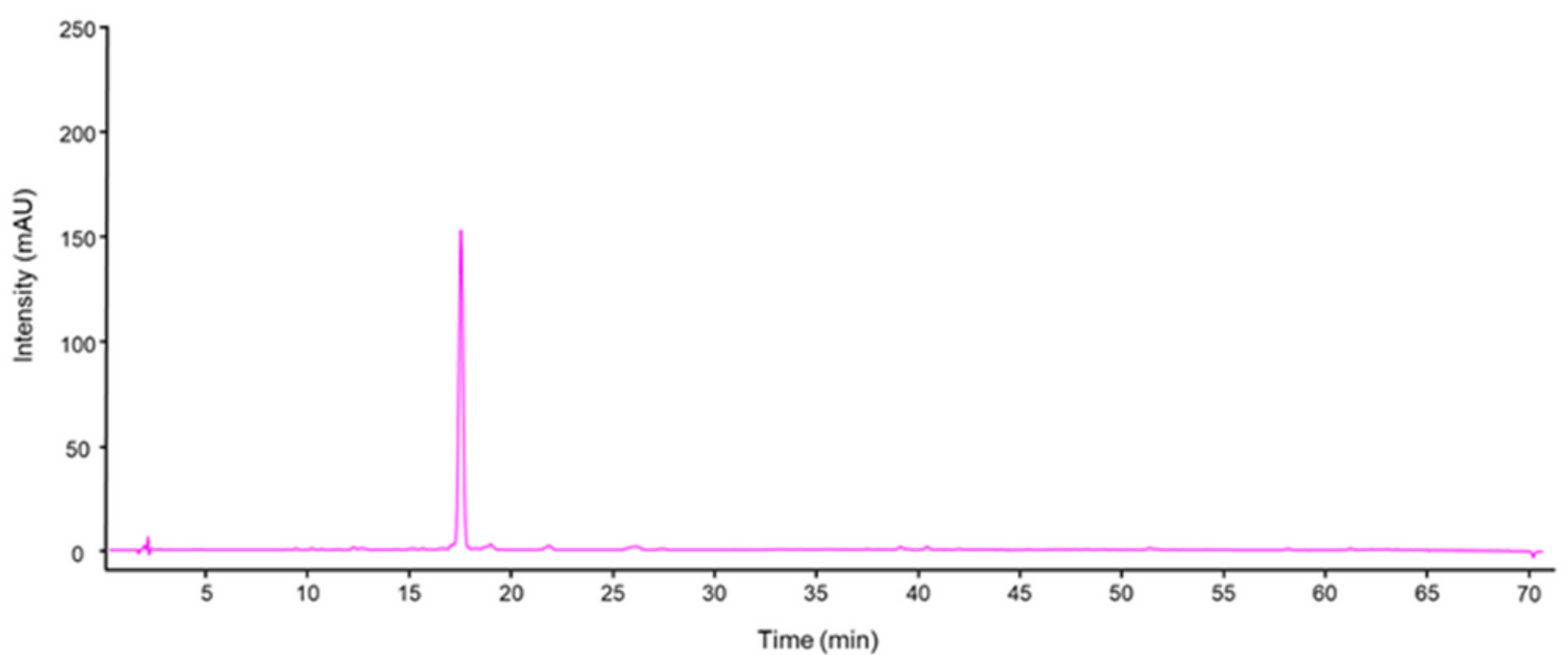

Figure 1

Representative chromatogram of cubiu extract (pink) and 5-Caffeoylquinic acid standard (gray). Chromatograms acquired at $320 \mathrm{~nm}$. 
(a)

Biofilm inhibition

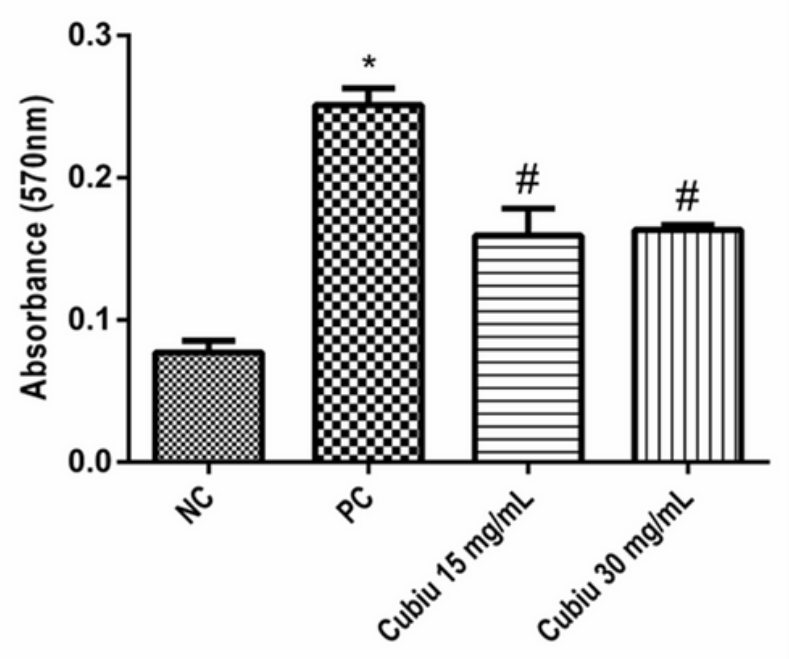

(b)

Biofilm destruction

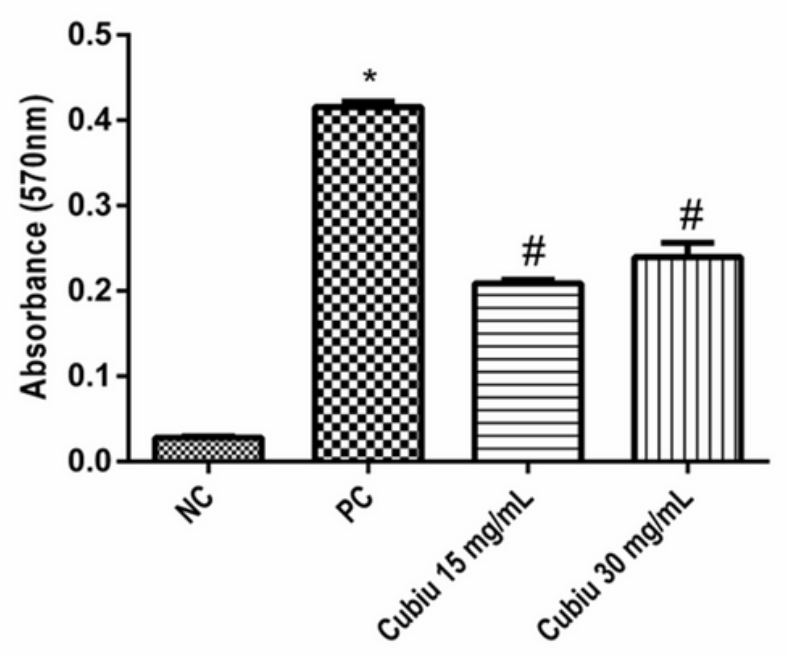

Figure 2

Biofilm formation inhibition and biofilm destruction. "a" corresponds to the inhibition of PA01 biofilm formation, while " $b$ " corresponds to the destruction of the PA01 biofilm. The results are demonstrated as absorbance values. Data were expressed as mean \pm standard deviation (SD). Values with $p<0.05$ were considered statistically significant. " " indicates a difference of negative control (NC), and "\#" indicates a difference of positive control (PC). 
(a)

Hemolysis $\mathrm{pH} 7,2$

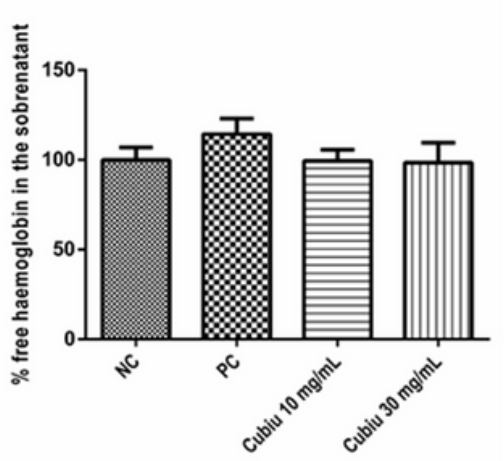

(d) (b)

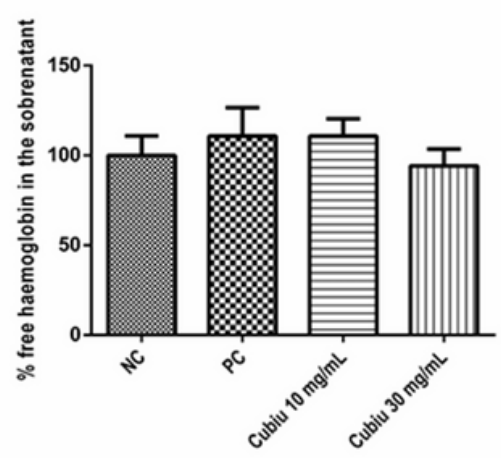

(c) Hemolysis $\mathrm{pH} 7,5$

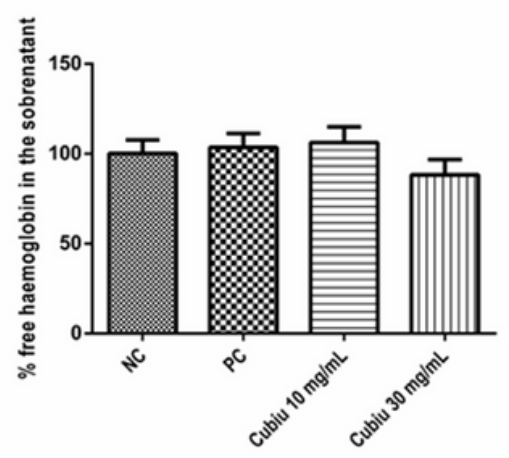

Partially activated thromboplastin time

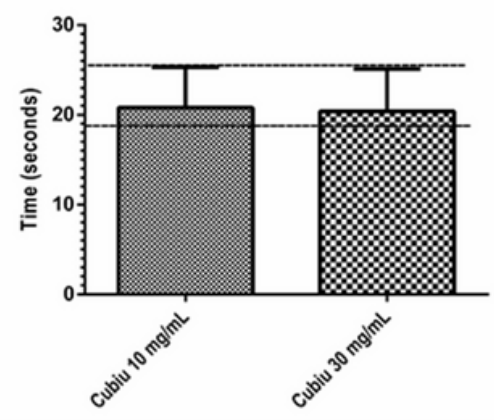

(e)

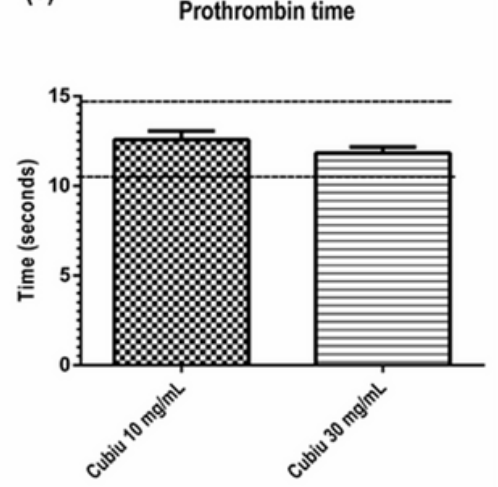

\section{Figure 3}

Hemocompatibility assays. The hemolytic activity at pH 7.2, 7.4, and 7.5 are represented as the letters "a," "b," and "c," respectively. The results are expressed as a percentage of the negative control. For the coagulation tests, the prothrombin time test (PT) is reported as the letter " $\mathrm{d}$ ", and the activated partial tromblopastin time test (aPTT) in the letter "e". For baseline PT values, the interval between 11 and $15 \mathrm{~s}$ was used, while for aPTT, the interval between 25 and $35 \mathrm{~s}$ was used as reference. Data were expressed as mean \pm standard deviation (SD). Values with $p<0.05$ were considered statistically significant. 
(a)

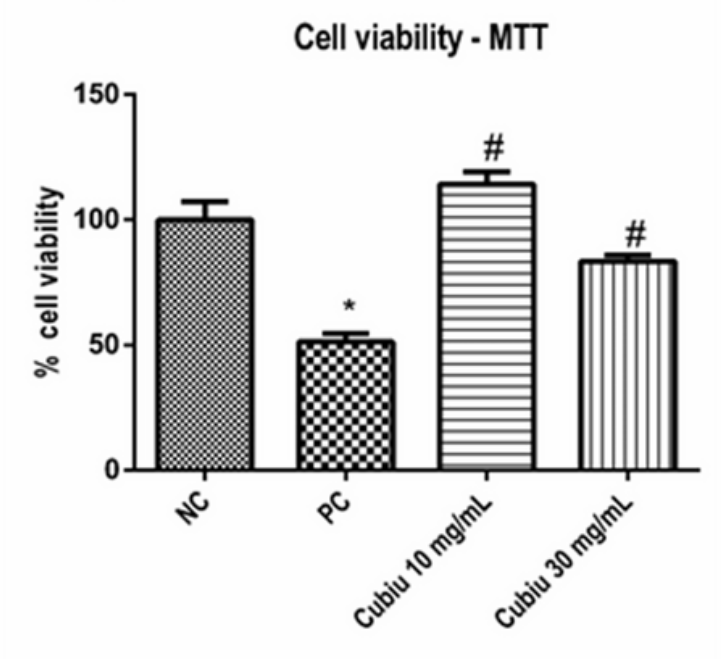

(c)

ROS total levels

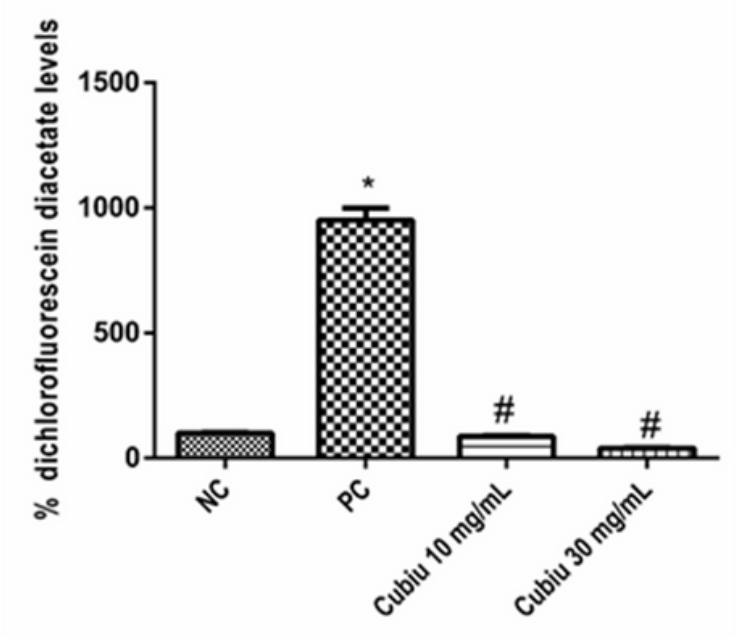

(b) Genotoxicity assay - PicoGreen®

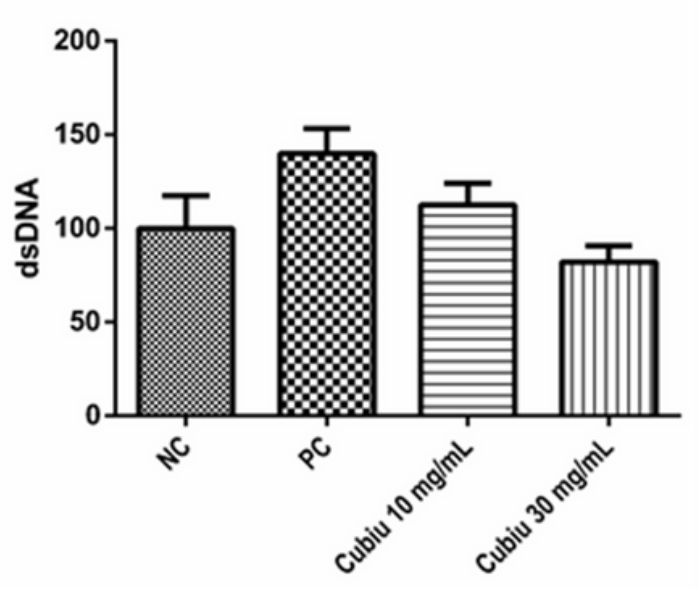

(d)

\section{Nitric oxide levels}

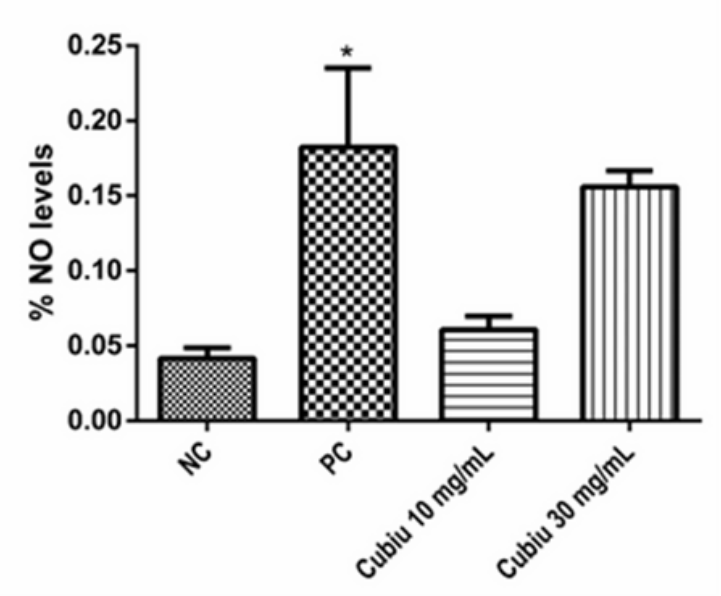

\section{Figure 4}

Toxicity and antioxidant assays. "a" corresponds to cell viability by MTT assay [3-(4,5-dimethylthiazol2yl)-2,5-diphenyltetrazoline bromide]. " $b$ " corresponds to the quantification quantity of free dsDNA (PicoGreen assay). "c" corresponds to the quantification of total levels of reactive oxygen species by 2',7'dichlorofluorescein diacetate (DCF) assay. "d" corresponds to the nitric oxide (NO) assay. The data are presented as $\%$ of the untreated control group. Data were expressed as mean \pm standard deviation (SD). Values with $p<0.05$ were considered statistically significant. " $*$ " indicates a difference of negative control $(\mathrm{NC})$, and "\#" indicates a difference of positive control (PC). 
(a)

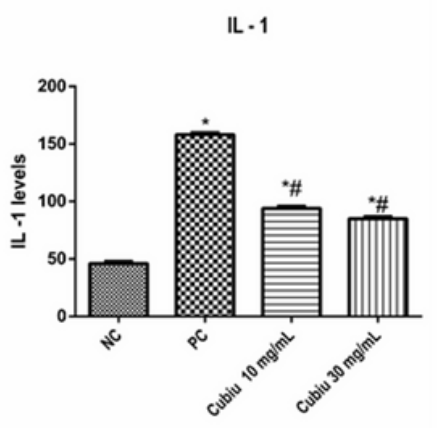

(e)

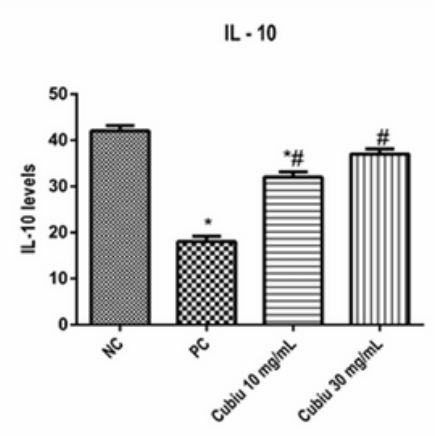

(b)

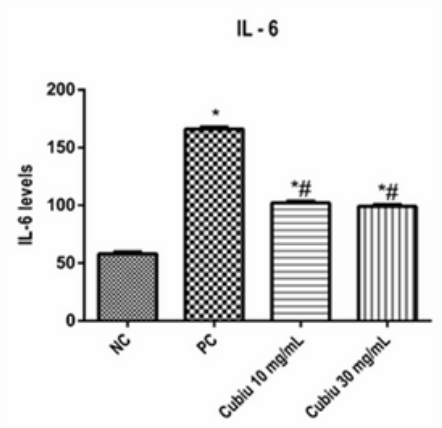

(c)

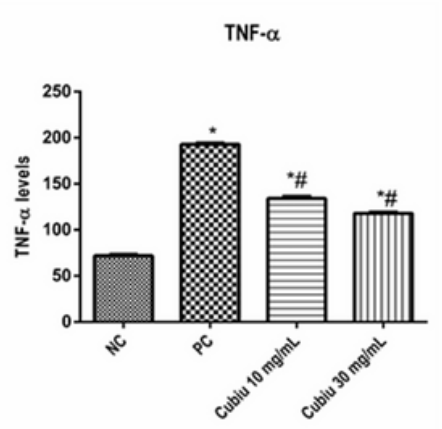

(d)

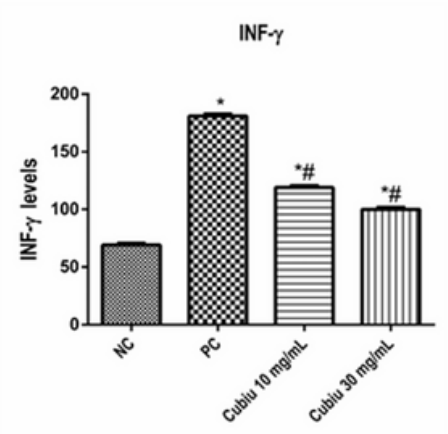

(f)

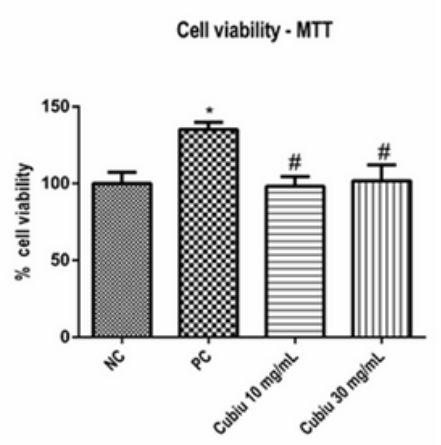

(g)

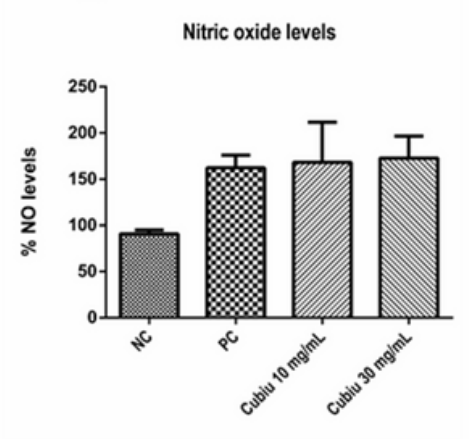

Figure 5

Evaluation of cubiu extract anti-inflammatory activity with phytohemagglutinin. The pro-inflammatory cytokines IL-1, IL-6, TNF-a and INF-g are demonstrated as the letters "a", "b", "c" and "d", respectively. The anti-inflammatory cytokine IL-10 is demonstrated as the letter "e", the results are expressed in $\mathrm{pg} / \mathrm{ml}$. "f" corresponds to the cellular viability by MTT assay (3-(4,5-dimethylthiazol-2yl)-2,5-diphenyltetrazoline bromide). " $g$ " corresponds to the nitric oxide (NO) assay, the data are presented as \% of the untreated control group. Data were expressed as mean \pm standard deviation (SD). Values with $p<0.05$ were considered statistically significant. " $"$ " indicates a difference of negative control (NC), and "\#” indicates a difference of positive control (PC). 
(a)

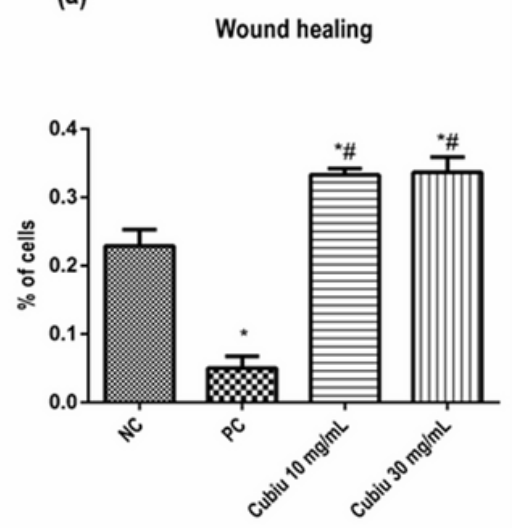

(d)

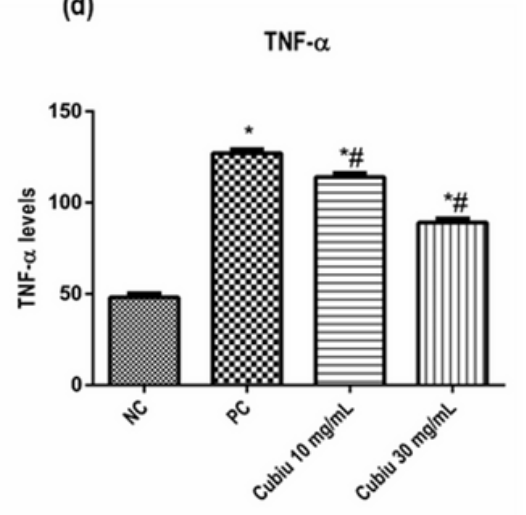

(b)

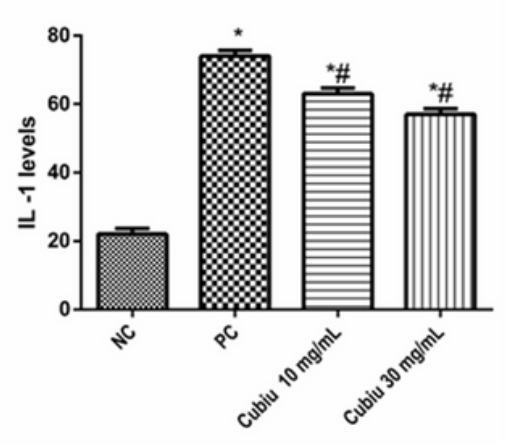

(e)

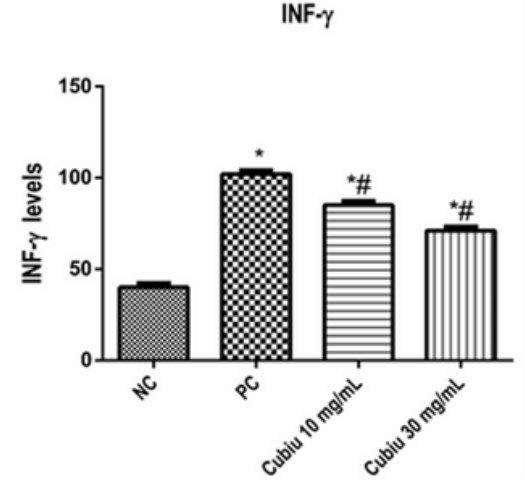

(c)

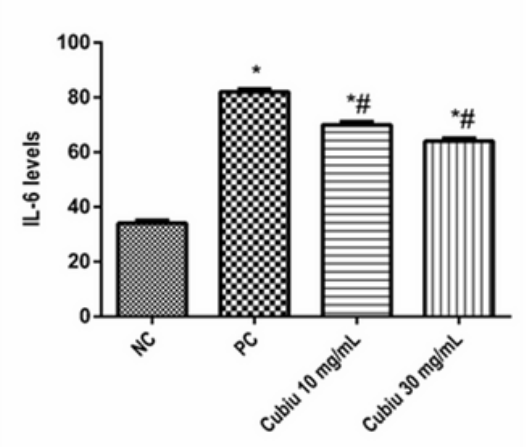

(f)

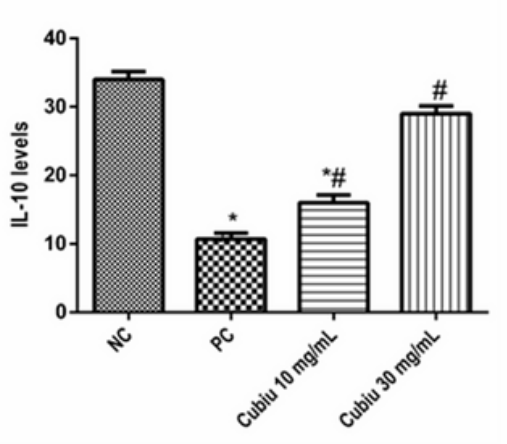

\section{Figure 6}

In vitro skin wound healing - scratch assay. "a" corresponds to skin wound healing activity, the results are demonstrated in \% of cells. The pro-inflammatory cytokines IL-1, IL-6, TNF- and INF-g are demonstrated as the letters "b", "c", "d" and "e", respectively. The anti-inflammatory cytokine IL-10 is demonstrated as the letter " $\mathrm{f}$ ". The results are expressed in $\mathrm{pg} / \mathrm{ml}$. Data were expressed as mean \pm standard deviation (SD). Values with $p<0.05$ were considered statistically significant. " $*$ " indicates a difference of negative control (NC), and "\#" indicates a difference of positive control (PC).

\section{Supplementary Files}

This is a list of supplementary files associated with this preprint. Click to download.

- Supplementaldata.xIsx 